\title{
Szénszállal erősített műanyag marásának vizsgálata
}

\section{Investigation of Milling of Carbon Fiber Reinforced Plastic}

\author{
Horváth Richárd, ${ }^{1}$ Stadler Róbert Gábor, Andrásfalvy Kristóf \\ Óbudai Egyetem, Bánki Donát Gépész és Biztonságtechnikai Mérnöki kar, Budapest, Magyarország \\ ${ }^{1}$ horvath.richard@bgk.uni-obuda.hu
}

\begin{abstract}
The utilization of fiber reinforced plastics has increased significantly in the past decades. Consequently, the demand for finishing and machining of such materials has also escalated. During machining the fiber reinforced materials exhibit machining problems dissimilar to the problems of metals. These are fiber pull-out, fiber breakage in the cutting zone, matrix smearing and delamination. The purpose of this experiment is to investigate the characteristics of the resultant force (Fe) during milling of carbon fiber reinforced plastic as a function of input machining parameters. For the force measurements CFR with perpendicular $\left(0^{\circ}-90^{\circ}\right)$ fiber orientation was machined. The experimental design involved the central composite design method. To analyze and evaluate the measurements the response surface methodology was applied.
\end{abstract}

Keywords: milling, cutting force, central composite design, RSM method.

\section{Összefoglalás}

A szálerősítésű műanyagok használata jelentősen megnőtt az elmúlt évtizedekben. Ezzel együtt megnőtt az igény az ilyen anyagok befejező megmunkálására, azok forgácsolására. A szálerősítésű anyagok forgácsolásakor viszont számos, a fémek forgácsolási hibáitól eltérő hiba jelentkezik, ilyen a szálkiszakadás, a szálak törése a forgácsolási zónában, a mátrixanyag elkenődése és a delamináció. Jelen vizsgálat célja, hogy a szénszállal erősített műanyag marása során feltárjuk az eredő forgácsolóerő (Fe) jellemzőit a bemenő forgácsolási paraméterek függvényében. A mérések során egymásra merőleges (0-90) szálelrendezésű anyagot martunk. A kísérlet során a középpontos kompozíciós kísérlet tervet használtuk. A kiértékelés során pedig a válaszfüggvények módszerét alkalmaztuk.

Kulcsszavak: CFR-marás, forgácsolóerő, középpontos kompozíciós kísérletterv, RSM-módszer.

\section{Bevezetés}

A műszaki célú szerkezeti anyagok új generációs családjába sorolhatóak a szálerősítésű kompozitok. Kedvező mechanikai tulajdonságainak köszönhetően napjainkban egyre jobban növekszik a szálerősítésű (pl. szén vagy üveg) anyagok felhasználása a különböző iparágakban. Az egyik legnagyobb felhasználó a repülőgépipar. $\mathrm{Az}$ 1. ábra a szénszálas kompozitok aeroszerkezetekben történő alkalmazásának folyamatosan növekvő tendenciáját mutatja [1]. A repülőgépgyártók a következő generációjú repülőgépeket már úgy tervezik, hogy a kompozitok aránya meg

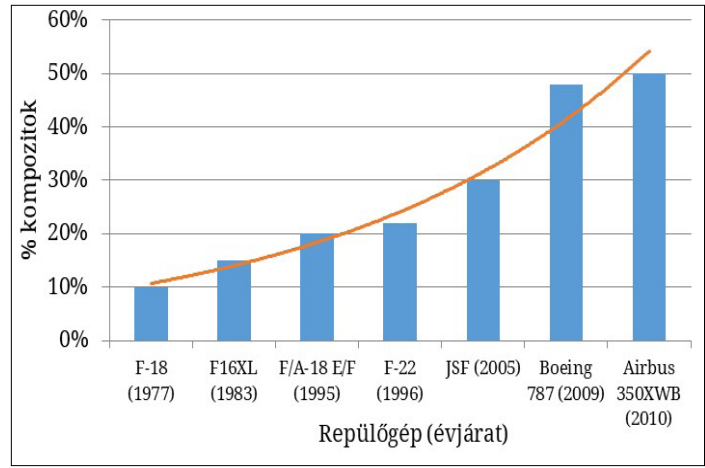

1. ábra. Kompozitok aránya az egyes konstrukciók aeroszerkezetében 
fogja haladni az 50\%-ot. Ez többek között tovább csökkentheti a tüzelőanyag-felhasználást, illetve a $\mathrm{CO}_{2}$-kibocsátást is 20-25\%-kal [2].

A szénszállal erősített műanyagok végső megmunkálása történhet forgácsolással. A technológiai előtervezés során fontos megfelelő pontossággal ismerni, hogy a bemenő forgácsolási paraméterek függvényében a forgácsolás során mekkora erők lépnek fel, és hogy ezek az erők milyen hatással vannak a megmunkálandó munkadarabra, valamint a szerszámra. Ezért napjainkban számos kutatás foglalkozik a szénszállal erősített műanyagok forgácsolással való megmunkálásával.

A szénszállal erősített polimerek és az üvegszállal erősített polimerek megmunkálhatóságával foglalkoznak átfogóan Meltem és Hasan [3] 2018as publikációjukban. Áttekintették az utóbbi évek kortárs publikációit a kompozitok hagyományos megmunkálásával kapcsolatban (esztergálás, marás, fúrás stb.). Az összefoglaló irodalmi áttekintés alapján az alábbi általános következtetések vonhatóak le:

- az előtolási sebesség növelése nagyobb nyomóerőt eredményez;

- a legkisebb delamináció kis forgácsolási sebességen és kis előtolási sebességen érhető el;

- a legkisebb átlagos felületi érdesség eléréséhez nagy forgácsolási sebesség és kis előtolási sebesség szükséges.

Mathivanan és társai [4] üvegszállal és szénszállal (GFRP és CFRP) erősített műanyagok forgácsolhatóságát vizsgálták zárt horony marása esetén. A munkadarabban a szálak egymásra merőlegesen voltak elhelyezve. A forgácsolási kísérletben (kilenc mérési pont) $\emptyset 10$ mm-es K10-es keményfém marót használtak, a forgácsolási paramétereket (forgácsolási sebesség és fogankénti előtolás) három szinten változtatták. Alapvetően az eredő erőt vizsgálták és megállapították, hogy különösen az előtolás növeli jobban az eredő erőt. Kis előtolást és nagy forgácsolási sebességet ajánlanak az ilyen típusú anyagok forgácsolásához.

Haijin és társai [5] szénszállal erősített műanyagot martak. A marási kísérletek során mérték a fellépő erőt, valamint a marás során keletkező hőmérsékletet. Középpontos kompozíciós kísérlettervet alkalmaztak, az elemzés során pedig a válaszfüggvények (RSM) módszerét. A bemenő paraméterek a forgácsolási sebesség, az előtolási sebesség és a fogásmélység voltak. Következtetésként azt vonták le, hogy az eredő erőt a legjobban az előtolási sebesség befolyásolja, míg a hőmérsékletre a forgácsolási sebesség van a legnagyobb hatással.
Çolak és Sunar [6] 32 laminált rétegből álló, szénszállal erősített kompozit marási vizsgálatát végezték el. A marások során $\phi 10 \mathrm{~mm}$ PCD-szerszámot használtak, és két szinten változtatták a forgácsolósebességet $(50 \mathrm{~m} / \mathrm{min}$ és $100 \mathrm{~m} / \mathrm{min})$, valamint öt szinten a fogankénti előtolást $(0,050$; 0,$075 ; 0,100 ; 0,125 ; 0,150$ mm). A vizsgálatok során mérték mind a három erőkomponenst, valamint a felületi érdességet. A méréseik alapján arra az eredményre jutottak, hogy kisebb forgácsolóerőt lehet elérni nagyobb forgácsolósebességen és kisebb előtoló-sebességen, míg a felületi érdesség (Ra) romlik az előtolási sebesség növelésével és a forgácsolási sebesség csökkentésével.

Yanli és társai [7] a szálorientáció, a forgácsolási sebesség, illetve az előtolási sebesség függvényében vizsgálta a marás során fellépő erőt, valamint a delaminációt. A marások során 0, 45, 90 és 135 fokonként martak egy 43 rétegű egyszálirányú szénszállal (TC35-12K / 150) erősített műanyagot. A laminált kompozit vastagsága $6 \mathrm{~mm}$, és a szálak térfogataránya megközelítőleg $60 \%$. A marások során három szinten változtatták a forgácsolási sebességet és az előtolási sebességet. A marásokat $\phi 8 \mathrm{~mm}$-es maróval végezték. Vizsgálataikban részletesen megállapították, hogy a forgácsoló erő komponensek hogyan függenek a száliránytól. Továbbá részletesen vizsgálták a delamináció jelenségét is.

Erol Kiliçkap és társai [8] 16 rétegü szénszállal erősített kompozitot martak, ahol a szálak egymásra merőlegesen helyezkedtek el. A marási kísérleteket két különböző fogszámú keményfém marószerszám (3 fogú és 4 fogú) alkalmazása mellett hajtották végre. A forgácsolási folyamat paraméterek közül három szinten határozták meg a forgácsolási sebességet $(31,4 ; 62,8 ; 94,2 \mathrm{~m} / \mathrm{min})$ és az előtolási sebességet (100, 150, $200 \mathrm{~mm} / \mathrm{min})$, míg a fogásmélységet $(1,5 \mathrm{~mm})$ állandó értéken tartották. A marások során mérték az erőkomponenseket és a mart felületek érdességét, valamint a felületen keletkezett delaminációs jelenségeket is vizsgálták. Azt a következtetést vonták le, hogy az előtolás növelésével az eredő erő is megnövekszik, valamint a 4 fogazattal rendelkező szerszámmal jobb eredményeket kaptak.

Geier N. és Szalay T. [9] szénszállal erősített kompozitot fúrtak és (spirál) martak. A fúrásokat egy SECO SD205A-11.138-53-12R1-C1 speciális gyémántbevonatú fúróval, míg a marásokat egy TIVOLY 82366511000 keményfém-végmaróval hajtották végre. A forgácsolási kísérletek során mérték a fellépő erőkomponenseket, a mart felületeket és a furatok érdességi paramétereit. 
Ezen felül a megmunkált felületeken vizsgálták a fellépő delaminációt. A mérések során kísérlettervet alkalmaztak, így 13 fúrási és 20 marási kísérletet végeztek. A mért eredményeket ANOVAmódszerrel elemezték. A forgácsolási folyamatváltozókat 5 szinten változtatták mind a két forgácsolási eljárásnál. Fúrásnál a forgácsolási sebességet $(50,65,100,135,150 \mathrm{~m} / \mathrm{min})$ és a fogankénti előtolást $(0,035 ; 0,043 ; 0,064 ; 0,078 ; 0,093 \mathrm{~mm})$. Marásnál a forgácsolási sebességet $(50,70,100$, $130,150 \mathrm{~m} / \mathrm{min})$, az előtolást $(0,020 ; 0,028 ; 0,040$; 0,051; 0,060 mm és a marás menet- emelkedését $(0,100 ; 0,068 ; 1,550 ; 2,410 ; 3,000$ mm). Munkájukban optimális folyamatváltozókat állapítottak meg, valamint arra a következtetésre jutottak, hogy a keményfém maróval végzett megmunkálás jobb minőségű furatokat eredményezett, mint a gyémántbevonatú fúróval végzett.

Ebben a cikkben egy szénszállal erősített műanyag marási vizsgálatait végezzük el, mérve a fellépő erőkomponenseket, valamint elemezzük azok eredőjét. Megvizsgáljuk a bemenő forgácsolási folyamatváltozók hatását az eredő erőre. Prediktív modellt építünk, mellyel technológiai előtervezésben megfelelő pontossággal becsülhető a fellépő eredő erő nagysága, hiszen a legtöbb elforduló hiba és a gyártott darab minőségi jellemzői (pl. delamináció, méretpontatlanság, száltörések a forgácsolási zónában, szélkiszakadások, felületi érdesség értékei) nagymértékben függnek a fellépő forgácsolási erőtől.

\section{Anyag és módszer}

\subsection{A kísérletben használt alapanyag és szerszám}

A marások során 26 rétegű (10 mm vastag), vákuuminfúziós eljárással készült, szénszállal erősített kompozitot martunk. A vázanyag típusa Zoltek Panex 35 szénszál, melynek főbb jellemzői: négyzetméterre vetített tömege $400 \mathrm{~g} / \mathrm{m}^{2}$; szakítószilárdsága $4137 \mathrm{MPa}$; rugalmassági modulusza $242 \mathrm{GPa}$; valamint az elemi szálak átmérője 7,2 $\mu \mathrm{m}$. A felhasznált epoxi gyanta típusa Araldite LY 1564, valamint a térhálósító típusa Aradur 3487. A felhasznált arányuk: 100 g gyanta/34 g térhálósító.

A szálakat tartalmazó rétegek egymásra merőlegesen helyezkedtek el (2. ábra). A próbatestet ф10mm-es szálerősítésű kompozitok megmunkálására specializált D-POWER GUF40100 kompreszsziós szármaróval végeztük. Ennek a szerszámnak nagy előnye, hogy csökkenti a laminált rétegek egymástól való eltávolodását.

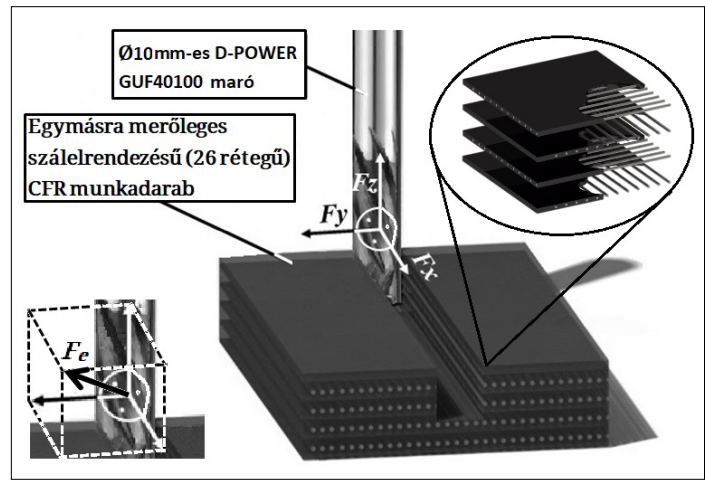

2. ábra. Forgácsolási kísérlet elrendezése, erőkomponensek iránya

\subsection{A kísérletben használt mérőeszközök és mért paraméterek}

A marási kísérleteket Mazak Nexus 410A-II megmunkáló központon végeztük. A marási kísérletek során, piezoelektromos elven működő KISTLER 9257b típusú erőmérő rendszert alkalmaztunk. Ennek segítségével mértük az $F_{x}, F_{y}$ és $F_{z}$ irányú erőkomponenseket. Az erőmérő mérési tartománya $F_{x}=F_{y}=-5-5 \mathrm{kN}$, valamint $\mathrm{F}_{\mathrm{z}}=-5-10 \mathrm{kN}$. A mért erőadatokat Kistler DynoWare szoftverrel elemeztük ki. A szerszámra és a munkadarabra az erőkomponensek eredője hat (1. ábra), ezért a mért három erőkomponens eredőjét $\left(F_{e}\right)$ vizsgáltuk:

$$
F_{e}=\sqrt{F_{x}^{2}+F_{y}^{2}+F_{z}^{2}}
$$

\subsection{Alkalmazott kísérletterv bemutatása}

A marási kísérletek középpontos kompozíciós kísérletterv alapján készültek. A bemenő változókat (forgácsolási sebesség, fogankénti előtolás, fogásmélység) három szinten változtattuk. A kiértékeléshez a válaszfüggvények módszerét használtuk. A szintek egymástól ekvidisztáns távolságra vannak (1. táblázat, 3. ábra). A mért kimenő változó az eredő erő $\left(F_{e}\right)$. Célunk az volt, hogy megtaláljuk a kapcsolatot a független bemenő változók $-x_{1}, x_{2}$, $X_{3}$ - és a függő kimenő változó $Y$ között:

$$
Y=\Omega\left(x_{1}, x_{2}, x_{3}\right)
$$

ahol $\Omega$ a válasz függvény, mely az alábbi általános alakban írható fel:

$$
\begin{array}{r}
Y=b_{0}+b_{1} \cdot x_{1}+b_{2} \cdot x_{2}+b_{3} \cdot x_{3}+b_{11} \cdot x_{1}^{2}+b_{22} \cdot x_{2}^{2}+ \\
+b_{33} \cdot x_{3}^{2}+b_{12} \cdot x_{1} \cdot x_{2}+b_{13} \cdot x_{1} \cdot x_{3}+b_{23} \cdot x_{2} \cdot x_{3}+\varepsilon
\end{array}
$$


ahol $b_{0}, b_{i}$ és $b_{i j}$ a számított koefficiensek; $x_{1}, x_{2}$ és $x_{3}$ a bemenő változók; $\varepsilon$ a hiba. A (3) modell figyelembe veszi a bemenő folyamatváltozókat, azok másodfokú tagjait, valamint ha van szignifikáns hatásuk, akkor a bemenő folyamatváltozók kereszthatásait.

\subsection{Az alkalmazott kísérletterv mérési pontjai}

A szakirodalom és a szerszámkatalógus ajánlásai alapján határoztuk meg a beállítandó forgácsolási paramétereket és azok szintjeit (1. táblázat).

A 1. táblázat alapján a mérési pontokat a forgácsolásiparaméter-tartományon a 3. ábra szemlélteti. A kísérletterv alapján a kocka sarokpontjait és tengelypontjait egyszer, míg a tervközéppontot alkotó folyamatváltozókkal hatszor martuk a kísérleti anyagot.

A kísérleti pontok elhelyezkedéséből adódó kísérleti pontokat és azok változóit ismerteti a 2. táblázat.

\section{Eredmények}

\subsection{A forgácsolási folyamatváltozók hatása az eredő erőre}

A 4. ábrán látható az eredményekből kapott főhatásábra.

A főhatás-ábrákból látszik, hogy a fogankénti előtolás és a fogásmélység növelésével az eredő erő nő.

\subsection{Prediktív modell az eredő forgácsolási erő becslésére}

A 3. táblázatban látható, hogy melyek azok a forgácsolási változók, amik a marási kísérletek során az eredő erő értékére szignifikáns hatással voltak (a bemenő folyamatváltozók lineáris tagjai szignifikáns hatásuktól függetlenül a modellben maradnak).

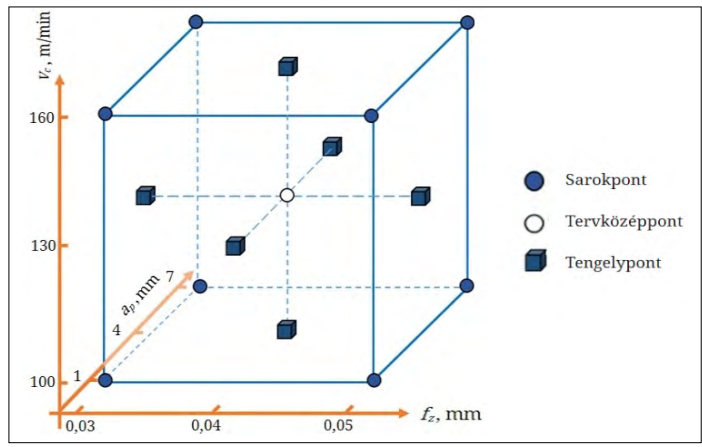

3. ábra. A kísérleti pontok elhelyezkedése a forgácsolási paramétertérben
1. táblázat. A bemenő változók értékei

\begin{tabular}{|c|l|c|c|c|}
\hline \multicolumn{2}{|c|}{ Folyamatváltozók } & \multicolumn{3}{|c|}{ Szintek } \\
\cline { 2 - 5 } & -1 & $\mathbf{0}$ & $\mathbf{1}$ \\
\hline$x_{1}$ & $\begin{array}{l}\text { forgácsolási sebesség }-v_{c}, \\
\text { m/min }\end{array}$ & 100 & 130 & 160 \\
\hline$x_{2}$ & előtolás $-f_{z}, \mathrm{~mm}$ & 0,03 & 0,04 & 0,05 \\
\hline$x_{3}$ & fogásmélység $-a_{p}, \mathrm{~mm}$ & 1 & 4 & 7 \\
\hline
\end{tabular}

2. táblázat. A 20 mérési pont mért és számolt eredó erö eredményei

\begin{tabular}{|c|c|c|c|c|c|}
\hline $\begin{array}{c}\text { Kísérleti } \\
\text { pontok }\end{array}$ & $\begin{array}{c}\mathbf{V}_{\mathbf{c}} \\
\mathbf{m} / \mathbf{m i n}\end{array}$ & $\begin{array}{c}\mathbf{f}_{\mathbf{z}} \\
\mathbf{m m}\end{array}$ & $\begin{array}{c}\mathbf{a}_{\mathbf{p}} \\
\mathbf{m m}\end{array}$ & $\begin{array}{c}\mathbf{F}_{\mathbf{e}} \\
\mathbf{N}\end{array}$ & $\begin{array}{c}\mathbf{F}_{\mathbf{e}} \\
\mathbf{N}\end{array}$ \\
\hline 1. & 100 & 0,03 & 1 & 26,57 & 22,83 \\
\hline 2. & 160 & 0,03 & 1 & 18,95 & 21,70 \\
\hline 3. & 130 & 0,04 & 1 & 21,03 & 26,07 \\
\hline 4. & 100 & 0,05 & 1 & 33,95 & 30,45 \\
\hline 5. & 160 & 0,05 & 1 & 31,17 & 29,32 \\
\hline 6. & 130 & 0,03 & 4 & 99,32 & 97,04 \\
\hline 7. & 100 & 0,04 & 4 & 117,31 & 123,17 \\
\hline 8. & 160 & 0,04 & 4 & 114,24 & 122,04 \\
\hline 9. & 130 & 0,04 & 4 & 133,70 & 122,61 \\
\hline 10. & 130 & 0,04 & 4 & 131,05 & 122,61 \\
\hline 11. & 130 & 0,04 & 4 & 127,07 & 122,61 \\
\hline 12. & 130 & 0,04 & 4 & 122,48 & 122,61 \\
\hline 13. & 130 & 0,04 & 4 & 118,16 & 122,61 \\
\hline 14. & 130 & 0,04 & 4 & 124,19 & 122,61 \\
\hline 15. & 130 & 0,05 & 4 & 142,72 & 148,18 \\
\hline 16. & 100 & 0,03 & 7 & 173,24 & 172,38 \\
\hline 17. & 160 & 0,03 & 7 & 174,36 & 171,25 \\
\hline 18. & 130 & 0,04 & 7 & 208,12 & 219,14 \\
\hline 19. & 100 & 0,05 & 7 & 267,26 & 267,03 \\
\hline 20. & 160 & 0,05 & 7 & 273,99 & 265,90 \\
\hline & & & & & \\
\hline
\end{tabular}

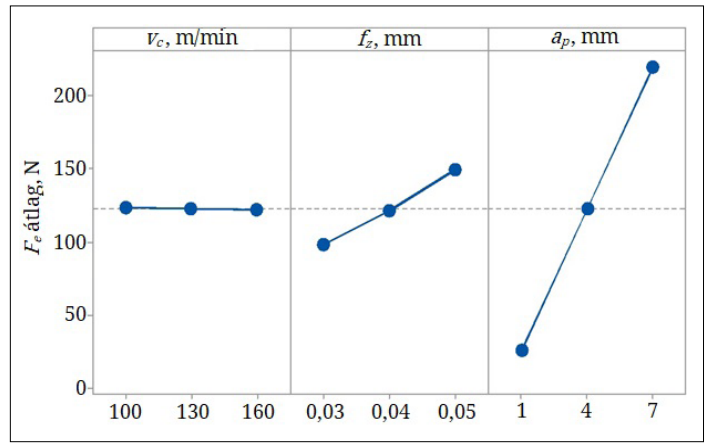

4. ábra. A forgácsolási folyamatváltozók hatása az eredő eröre 
3. táblázat. Szignifikanciavizsgálat eredménye $(\checkmark-a$ folyamatváltozónak van hatása az eredő eröre, X - a folyamatváltozónak nincs hatása az eredő eröre)

\begin{tabular}{|c|c|}
\hline Forgácsolási faktorok & \\
\hline$v_{c}$ & $\checkmark$ \\
\hline$f_{z}$ & $\checkmark$ \\
\hline$a_{p}$ & $\checkmark$ \\
\hline$v_{c}^{2}$ & $\mathrm{X}$ \\
\hline$f_{z}^{2}$ & $\mathrm{X}$ \\
\hline$a_{p}^{2}$ & $\mathrm{X}$ \\
\hline$v_{c} \cdot f_{z}$ & $\mathrm{X}$ \\
\hline$v_{c} \cdot a_{p}$ & $\mathrm{X}$ \\
\hline$f_{z} \cdot a_{p}$ & $\checkmark$ \\
\hline
\end{tabular}

A szignifikanciavizsgálat elvégzése után az eredő forgácsolóerőre ható tényezőkből a következő prediktív modellt állítottuk fel:

$F_{e}=10,1-0,0188 \cdot v_{c}-344 \cdot f_{z}+3,17 \cdot a_{p}+725,2 \cdot f_{z} \cdot a_{p}$

A prediktív modell (4) grafikus ábrázolását mutatja a forgácsolási folyamatváltozók függvényében az 5. ábra, amelyről jól látható, hogy a minimális forgácsolási erőt a legkisebb előtolásnál és a legkisebb fogásmélységnél kapjuk.

A prediktív modell akkor tekinthető a technológiai előtervezésben megfelelőnek, ha a reziduumok (mért és a számított értékek közötti különbség - reziduum) várható értékei nulla közeliek, és a reziduumértékek szórása minél kisebb. A 6. ábrán látható a mért és számított eredmények közötti különbségek ábrázolása normalitás-hálón. Jól látható, hogy az eredő erő becslése-

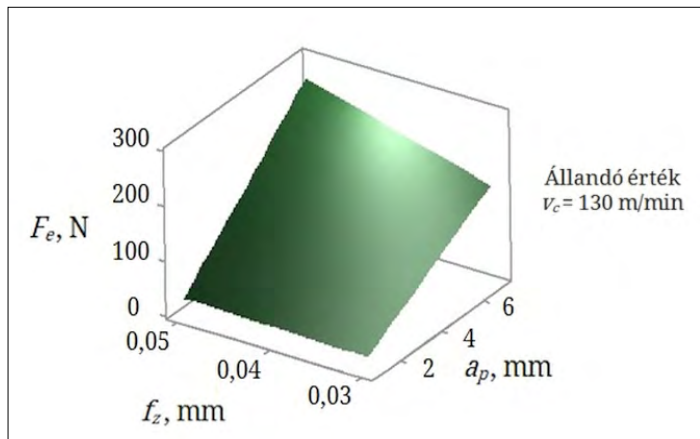

5. ábra. A prediktív modell (4) grafikai ábrázolása kor a hibák várható értéke közel zérus, a hibák eloszlása jól közelíti a normálist, azok szórása $\pm 5,7 \mathrm{~N}$.

\section{Következtetések}

Jelen kutatásban szénszálerősítésű kompozitanyag marásának vizsgálatát végeztük el középpontos kompozíciós kísérletterv segítségével. A forgácsolási folyamatváltozókat (forgácsolási sebesség, fogankénti előtolás, fogásmélység) három szinten változtattuk és mértük a forgácsolóerő-komponenseket, majd vizsgáltuk az eredő forgácsolási erőt. Főhatásábrával elemeztük a forgácsolási folyamatváltozók hatását a vizsgált jellemzőkre, prediktív modellt készítettünk az eredő forgácsolóerő becslésére, mely a technológiai előtervezést segítheti. Vizsgálatainkból az alábbi következtetések vonhatók le:

- az eredő forgácsolóerőre a forgácsolási sebesség van a legkisebb (elhanyagolható) hatással;

- az előtolás és a fogásmélység növelésével az eredő forgácsolási erő növekszik;

- a legnagyobb hatást a forgácsoláskor keletkező eredő erőre a fogásmélység gyakorolja;

- prediktív modellt hoztunk létre az eredő erő becslésére a forgácsolási változók vizsgált tartományán, mellyel \pm 5 ,7 N szórással lehet az eredő erő értékét meghatározni.

\section{Köszönetnyilvánítás}

A szerzők köszönetüket szeretnék kifejezni a KANDSI Kft.-nek (AKOBEZ), hogy biztosította az egyedileg gyártott munkadarabokat, illetve a GranTOOL Kft.nek, hogy biztosította a vizsgálatok elvégzéséhez szükséges szerszámot.

Jelen cikk az Emberi Erőforrások Minisztériuma ÚNKP-2018-1-I kódszámú Új Nemzeti Kiválóság Programjának támogatásával készült.

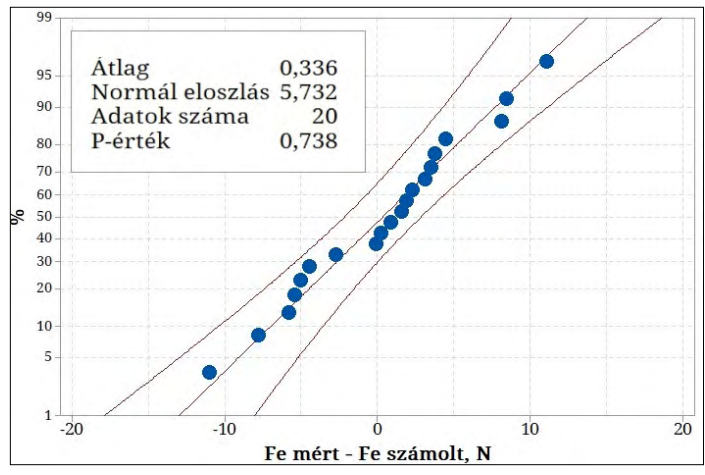

6. ábra. A mért és számított eredmények reziduumainak ábrázolása normalitáshálón 


\section{Szakirodalmi hivatkozások}

[1] Hashish M., Kent W. A.: Trimming of CFRP aircraft components. In: WJTA-IMCA conference and Expo, 2013. September

[2] Timmis A. J., Hodzic A., Koh L., Bonner M., Soutis C., Schäfer A. W., Dray L.: Environmental impact assessment of aviation emission reduction through the implementation of composite materials. The International Journal of Life Cycle Assessment, 20/2. (2015) 233-243. https://doi.org/10.1007/s11367-014-0824-0

[3] Karataş M. A., Gökkaya H.: A review on machinability of carbon fiber reinforced polymer (CFRP) and glass fiber reinforced polymer (GFRP) composite materials. Defence Technology, 14/4. (2018) 318-326.

https://doi.org/10.1016/j.dt.2018.02.001

[4] Mathivanan N. R., Mahesh B. S., Shetty, H. A.: An experimental investigation on the process parameters influencing machining forces during milling of carbon and glass fiber laminates. Measurement, 91. (2016) 39-45. https://doi.org/10.1016/j.measurement.2016.04.077

[5] Wang H., Sun J., Li J., Lu L., Li N.: Evaluation of cutting force and cutting temperature in milling carbon fiber-reinforced polymer composites. The International Journal of Advanced Manufacturing Technology, 82. (2016) 9-12. 1517-1525. https://doi.org/10.1007/s00170-015-7479-2

[6] Çolak O., Sunar T.: Cutting forces and $3 D$ surface analysis of CFRP milling with PCD cutting tools. Procedia CIRP, 45. (2016) 75-78. https://doi.org/10.1016/j.procir.2016.03.091

[7] He Y., Qing H., Zhang S., Wang D., \& Zhu S.: The cutting force and defect analysis in milling of carbon fiber-reinforced polymer (CFRP) composite. The International Journal of Advanced Manufacturing Technology, 93/5-8. (2017) 1829-1842. https://doi.org/10.1007/s00170-017-0613-6

[8] Kiliçkap E., Yardimeden A., Çelik Y. H.: Investigation of experimental study of end milling of CFRP composite. Science and Engineering of Composite Materials, 22/1. (2015) 89-95. https://doi.org/10.1515/secm-2013-0143

[9] Geier N., Szalay T.: Optimisation of process parameters for the orbital and conventional drilling of uni-directional carbon fibre-reinforced polymers (UD-CFRP). Measurement, 110. (2017) 319-334.

https://doi.org/10.1016/j.measurement.2017.07.007 